\title{
Neurolmages
}
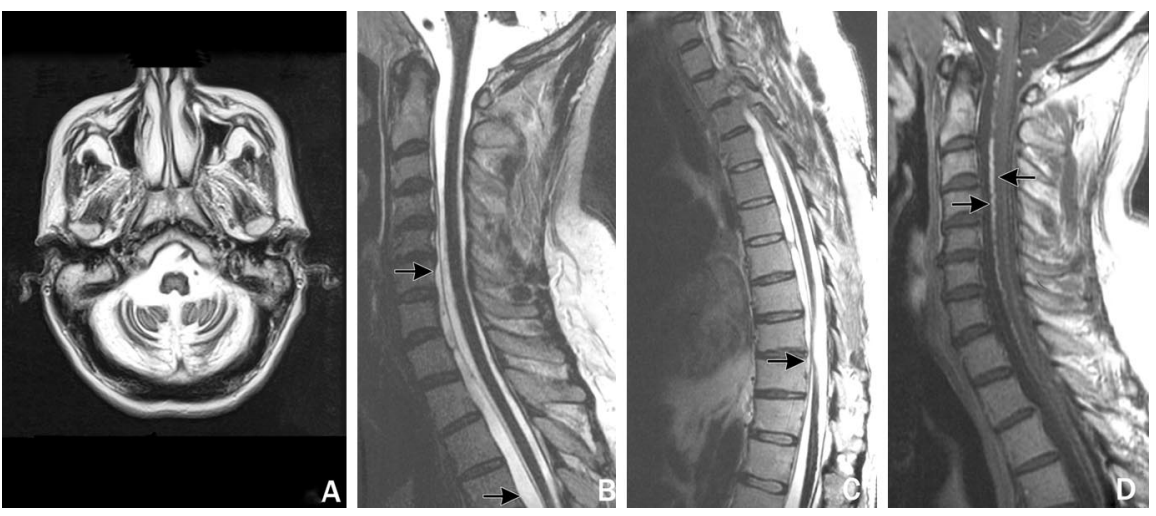

Figure. (A) Axial T2-weighted magnetic resonance $(M R)$ image shows diffuse hypointensities over the cerebellar folia and brainstem. (B) Sagittal T2weighted MR with contrast reveals nonenhancing CSF collection ventral to the spinal cord from C4 to T9. (C) Sagittal T2-weighted MR image shows ventral spinal cord tethering at T9. (D) MR spinal angiography shows enhancing vessels ventral to the cervical cord.

\section{Unusual neuroimaging in superficial siderosis}

J.A. Wilden, BS; N. Kumar, MD; H.R. Murali, MD;

E. Paul Lindell, MD; and D.H. Davis, MD, Rochester, $M N$

Superficial CNS siderosis from bleeding into the subarachnoid space causes sensorineural hearing loss and cerebellar ataxia. Spinal origins of superficial siderosis are rare but can include nerve root pathology. ${ }^{2}$

A 42-year-old man presented with an 8-year history of gait difficulty, dysarthria, and hearing loss. Past history was remarkable for a motor vehicle accident at age 10. Abnormalities on neurologic examination included decreased hearing, dysarthria, positive Babinski, and a wide-based gait. Head MRI demonstrated vermian atrophy and hypointense signal along the cerebellar surface and brainstem (figure, A). Postgadolinium MR revealed prominent vessels along the ventral brainstem. Cerebral angiography was negative. MRI of the spine revealed pial siderosis of the cord

Address correspondence and reprint requests to Dr. Neeraj Kumar, Department of Neurology, Mayo Clinic Bldg. E-8 A, Mayo Clinic Rochester, 200 First Street SW, Rochester, MN 55905; e-mail: kumar.neeraj@mayo.edu and cauda with peripheralization of roots suggesting arachnoiditis. Spine MRI showed a nonenhancing fluid collection ventral to the cervical cord (figure, B), tethered cord at T9 (figure, C), and enhancing vessels ventral to the cervical cord (figure, D). Invasive spinal angiography was negative. Surgery was performed with the intent of releasing a cord herniation at T9 but no dural defect was found. A left-sided nerve root avulsion was identified at T10.

Cerebrospinal fluid examination done after the surgery showed persisting subarachnoid hemorrhage. A dynamic CT myelogram identified a dural defect communicating with a fluid-filled cavity at T1-2. This defect was successfully repaired and a subsequent CSF study showed no red blood cells. The extensive siderosis may have contributed to sclerosis of the epidural plexus of veins, leading to venous hypertension.

1. Fearnley JM, Stevens JM, Rudge P. Superficial siderosis of the central nervous system. Brain 1995;118:1051-1066.

2. Kole MK, Steven D, Kirk A, Lownie SP. Superficial siderosis of the central nervous system from a bleeding pseudomeningocele: case illustration. J Neurosurg 2004;100:718. 


\title{
Neurology
}

\author{
Unusual neuroimaging in superficial siderosis \\ J. A. Wilden, N. Kumar, H. R. Murali, et al. \\ Neurology 2005;65;489 \\ DOI 10.1212/01.wnl.0000177924.27690.45
}

This information is current as of August 8, 2005

\section{Updated Information \& Services \\ Supplementary Material}

\section{References}

Citations

Subspecialty Collections

Permissions \& Licensing

Reprints including high resolution figures, can be found at:

http://n.neurology.org/content/65/3/489.full

Supplementary material can be found at:

http://n.neurology.org/content/suppl/2007/04/02/65.3.489.DC1

This article cites 2 articles, 0 of which you can access for free at: http://n.neurology.org/content/65/3/489.full\#ref-list-1

This article has been cited by 8 HighWire-hosted articles: http://n.neurology.org/content/65/3/489.full\#\#otherarticles

This article, along with others on similar topics, appears in the following collection(s):

\section{All Spinal Cord}

http://n.neurology.org/cgi/collection/all_spinal_cord MRI

http://n.neurology.org/cgi/collection/mri

Information about reproducing this article in parts (figures,tables) or in its entirety can be found online at:

http://www.neurology.org/about/about_the_journal\#permissions

Information about ordering reprints can be found online:

http://n.neurology.org/subscribers/advertise

Neurology ${ }^{\circledR}$ is the official journal of the American Academy of Neurology. Published continuously since 1951, it is now a weekly with 48 issues per year. Copyright . All rights reserved. Print ISSN: 0028-3878. Online ISSN: 1526-632X.

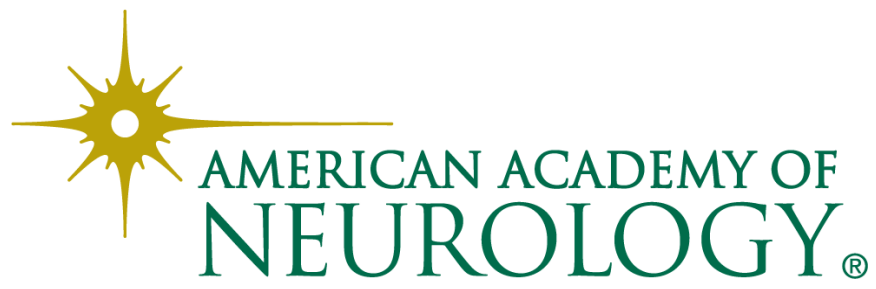

